\title{
HUBUNGAN DUKUNGAN KELUARGA DENGAN KUALITAS HIDUP DIABETES MELITUS TIPE 2 DI PUSKESMAS PADEMAWU
}

\author{
The Correlation between Family Support with Quality of Life Diabetes Mellitus Type 2 in Pademawu \\ PHC
}

\author{
Wulan Meidikayanti ${ }^{1}$, Chatarina Umbul Wahyuni ${ }^{2}$ \\ ${ }^{1}$ FKM Universitas Airlangga, wulan.meidika@gmail.com \\ ${ }^{2}$ Departemen Epidemiologi FKM Universitas Airlangga, chatarina.uw@ fkm.unair.ac.id \\ Alamat Korespodensi: Departemen Epidemiologi Fakultas Kesehatan Masyarakat Universitas Airlangga \\ Surabaya, Jawa Timur, Indonesia
}

\begin{abstract}
ABSTRAK
Diabetes Melitus (DM) Tipe 2 merupakan jenis tipe DM yang diderita hampir 90\% pasien dengan diagnosis DM di dunia. Penderita Diabetes Melitus tipe 2 membutuhkan perawatan dan pengobatan jangka panjang untuk memperpanjang umur serta meningkatkan kualitas hidup. Penelitian ini bertujuan untuk menganalisis hubungan dukungan keluarga dengan kualitas hidup penderita DM tipe 2. Jenis penelitian adalah observasional analitik dengan desain studi cross sectional. Populasi penelitian adalah semua penderita DM tipe 2 yang berkunjung di Pusat kesehatan masyarakat (Puskesmas) Pademawu pada bulan Mei-Juni 2017. Jumlah sampel adalah 50 responden yang dipilih secara acak menggunakan teknik simple random sampling. Variabel yang diteliti adalah karakteristik responden (usia, jenis kelamin, tingkat pendidikan, lama menderita, komplikasi), dan dukungan keluarga. Hasil uji dengan chi square dengan tingkat kemaknaan 5\% $(\alpha=0,05)$ menunjukkan variabel yang berhubungan signifikan dengan variabel kualitas hidup DM tipe 2 adalah dukungan keluarga $(\mathrm{p}=0,001)$ dan komplikasi DM $(\mathrm{p}=0,011)$. Kesimpulan dalam penelitian ini adalah variabel dukungan keluarga dan komplikasi mempunyai hubungan yang signifikan dengan kualitas hidup DM tipe 2 di Puskesmas Pademawu, Kabupaten Pamekasan, sehingga petugas kesehatan di Puskesmas Pademawu diharapkan lebih meningkatkan promosi kesehatan mengenai pentingnya dukungan keluarga terhadap penderita untuk memperpanjang umur penderita DM tipe 2.
\end{abstract}

Kata kunci: diabetes melitus tipe 2, dukungan keluarga, kualitas hidup, penyakit tidak menular

\begin{abstract}
Diabetes Mellitus (DM) Type 2 is one type of DM that affects nearly $90 \%$ of patients with a diagnosis of DM in the world. DM type 2 patients need long-term care and treatment to prolong life and improve quality of life. This study aims to analyze the relationship of family support with the quality of life of patients with DM type 2. This type of research is observational analytic with a cross-sectional study design. The study population was all patients with DM type 2 who visited the Public health center (PHC) of Pademawu in May - June 2017. The number of samples was 50 respondents who were randomly selected using a simple random sampling technique. The variables studied were the characteristics of respondents (age, sex, level of education, length of suffering, complications), and family support. The results of the chi-square test with a significance level of $5 \%(\alpha=0.05)$ showed that variables significantly related to the quality of life DM type 2 were family support $(p=0.001)$ and DM complications $(p=0.011)$. The conclusion in this study is the variable of family support and complications have a significant relationship with the quality of life of DM type 2 in PHC of Pademawu, Pamekasan District so that health workers in PHC of Pademawu are expected to further enhance health promotion regarding the importance of family support to patients to extend the life of patients with DM type 2.
\end{abstract}

Keywords: diabetes mellitus type 2, family support, quality of life, non-communicable disease 


\section{PENDAHULUAN}

Penyakit tidak menular merupakan penyebab kematian utama secara global. Salah satu jenis penyakit tidak menular yang selalu mengalami peningkatan dari tahun ke tahun adalah penyakit diabetes mellitus tipe 2. Diabetes mellitus tipe 2 merupakan penyakit kronis yang terjadi ketika pankreas tidak dapat menghasilkan hormon insulin yang cukup atau ketika tubuh tidak efektif menggunakan insulin yang dihasilkan (WHO, 2011). Penderita didiagnosis DM apabila kadar glukosa darah puasa lebih dari $126 \mathrm{mg} /$ dl atau kadar glukosa darah sewaktu lebih dari 200 $\mathrm{mg} / \mathrm{dl}$.

Angka kejadian DM di dunia dari tahun ke tahun selalu mengalami peningkatan. Data terakhir dari World Health Organization (WHO) menunjukkan pada tahun 2000 sebanyak 150 juta penduduk dunia menderita DM dan angka ini akan menjadi dua kali lipat sampai pada tahun 2025 (WHO, 2014). International Diabetes Federation (2014) telah melaporkan terdapat kematian sebesar 4,6 juta setiap tahunnya dan lebih dari 10 juta pasien mengalami kelumpuhan dan komplikasi seperti serangan jantung, stroke, gagal ginjal, kebutaan dan amputasi.

Diabetes mellitus tipe 2 merupakan tipe diabetes yang sering ditemukan di dunia. Pada orang dewasa, DM tipe 2 di dunia sebesar $90-95 \%$ kasus dari pada tipe diabetes yang lain seperti diabetes mellitus tipe 1 dan gestasional. Di antara 29,1 miliar penderita penyakit diabetes di Amerika Serikat, 8,1 miliar penderita tidak menyadari bahwa mereka memiliki penyakit diabetes ini. Pada usia 20 tahun keatas, lebih dari 10 orang menderita komplikasi akibat diabetes sedangkan pada usia 65 tahun ke-atas, kasus DM tipe 2 ini meningkat 1-4 kali lipat (IDF, 2013).

Studi International Diabetes Federation pada tahun 2013 penyakit DM diderita oleh 382 juta orang di seluruh dunia. Pada usia 20 tahun keatas, lebih dari 10 orang menderita komplikasi akibat diabetes sedangkan pada usia 65 tahun ke-atas, kasus DM tipe 2 ini meningkat 1-4 kali lipat. Indonesia merupakan negara yang menduduki urutan ketujuh dengan penderita DM sebanyak 7,6 juta jiwa dan diperkirakan akan terus meningkat enam persen setiap tahunnya (Rachmaningtyas, 2013).

Peningkatan angka insiden diabetes mellitus tipe 2 ini diikuti oleh peningkatan kejadian komplikasi. Komplikasi yang dialami penderita bervariasi diantaranya komplikasi fisik, psikologis, sosial dan ekonomi. Komplikasi fisik yang timbul berupa kerusakan mata, kerusakan ginjal, penyakit jantung, tekanan darah tinggi, stroke bahkan sampai menyebabkan gangren. Penyakit diabetes juga dapat kualitas hidup dari penderitanya, seperti kesehatan psikologi, fungsi fisik, dan peranan sosial. Kualitas hidup merupakan salah satu kriteria utama untuk mengetahui intervensi pelayanan kesehatan seperti morbiditas, mortalitas, fertilitas dan kecacatan.

Di Indonesia, penelitian yang dilakukan mengenai kualitas hidup telah dilakukan oleh Larasati (2012), di Rumah Sakit Abdul Moeloek Lampung yang memperoleh gambaran bahwa dari 89 responden pasien DM tipe 2 sebanyak 59,6\% memiliki kualitas hidup sedang, 27,0\% memiliki kualitas hidup baik dan 13,5\% memiliki kualitas hidup buruk. Penelitian Pertiwi (2013) di Poliklinik RSUD Panembahan Senopati, dari 49 pasien didapatkan kualitas hidup buruk sebesar 55,1\% dan baik sebesar 44,9\%. Dari penelitian terdahulu membuktikan bahwa responden DM tipe 2 terbukti memiliki kualitas hidup lebih rendah daripada responden yang tidak memilikinya. Pasien juga mengatakan saat diketahui memiliki penyakit DM tipe 2, pasien tidak dapat bekerja lagi seperti biasanya terutama yang telah mengalami komplikasi dengan penyakit lainnya.

Dukungan keluarga diyakini memiliki pengaruh terhadap kualitas hidup penderita DM. Keluarga merupakan bagian penting dari seseorang begitu pula dengan penderita DM. Penderita DM tipe 2 diasumsikan memiliki masa-masa sulit seperti berbenah diri, sering mengontrol gula darah, pola makan, dan aktivitas. Noviarini dkk (2013), mengungkapkan bahwa salah satu faktor yang dapat meningkatkan kualitas hidup adalah adanya dukungan keluarga, pola diet sehat, dan aktivitas fisik.

Dukungan keluarga dan kepedulian dari orangorang terdekat penderita diabetes mellitus memberikan kenyamanan, perhatian, kasih sayang, dan motivasi pencapaian kesembuhan dengan sikap menerima kondisinya. Hal tersebut dapat teramati melalui ungkapan salah satu penderita diabetes mellitus yang menyebutkan bahwa melalui usahanya serta bantuan dari orang-orang terdekat, penderita tersebut dapat teratur mengonsumsi obat sesuai dosis yang diberikan dokter. Penelitian Yusra (2010), menyatakan bahwa hasil wawancara dengan lima orang pasien DM tipe 2 , dua orang diantaranya mengatakan sudah bosan dengan penyakitnya dan merasa telah membebani keluarga, sedangkan tiga pasien lainnya merasa sulit melakukan ibadah dan kurang diperhatikan keluarganya. Oleh sebab itu, kondisi penyakit DM tipe 2 menimbulkan masalah psikologis dan fisik yang berfokus pada pentingnya dukungan orang sekitar terutama keluarga. 
Pada tahun 2012 terdapat 25,1\% kasus di yang berasal dari Surabaya, Jawa Timur. Kasus DM ini juga mengalami peningkatan menjadi $30,2 \%$ pada tahun 2013. Diabetes Mellitus merupakan penyakit yang berada pada peringkat ke-5 dari 49 penyakit menular dan penyakit tidak menular di RS Sentinel di Jawa Timur (Retnowati, 2015).

Data Dinkes Provinsi Jawa Timur mengenai STP Puskesmas (2017), menyatakan penemuan kasus diabetes mellitus di kabupaten Pamekasan umumnya mengalami jumlah yang berbeda-beda tiap tahun. Pada tahun 2013 mengalami peningkatan sebesar 1700 kasus namun 2 tahun berikutnya mengalami penurunan. Tahun 2016 mengalami peningkatan kasus kembali sebanyak 1742 kasus.

Hasil survei dari Dinas Kesehatan Kota Pamekasan tahun 2012 terdapat jumlah penderita Diabetes Mellitus usia 50-70 tahun terdapat sejumlah 2147 orang, total jumlah lansia di Puskesmas Pademawu sejumlah 3461 lansia sehat maupun yang sakit, sedangkan lansia yang menderita penyakit DM di wilayah kerja puskesmas Pademawu sejumlah 214 lansia. Menurut data medical record Puskesmas Pademawu kabupaten Pamekasan selalu terjadi peningkatan dari tahun ke tahun.

Tingginya kasus DM tipe 2 merupakan ancaman bagi status kesehatan masyarakat di wilayah kerja puskesmas. Penyakit DM tipe 2 yang tidak segera ditangani dapat menimbulkan berbagai permasalahan fisik maupun psikologis. Salah satu permasalahan adalah komplikasi DM tipe 2 yang akan semakin menurunkan kualitas hidup penderita. Penurunan kualitas hidup DM tipe 2 dapat disebabkan oleh faktor-faktor seperti kurangnya dukungan keluarga maupun sosial demografi. Oleh karena itu, peneliti tertarik untuk mengetahui hubungan dukungan keluarga dengan kualitas hidup penderita DM, di mana belum pernah dilakukan penelitian sejenis di Puskesmas Pademawu, Kabupaten Pamekasan.

Tujuan daripenelitianiniadalah untukmenganalisis hubungan dukungan keluarga dengan kualitas hidup penderita DM di Puskesmas Pademawu, menganalisis hubungan variabel umur, jenis kelamin, tingkat pendidikan, lama menderita DM dan komplikasi DM dengan kualitas hidup penderita DM tipe 2 .

\section{METODE}

Penelitian ini merupakan jenis penelitian observasional analitik dengan desain penelitian crosssectional yaitu pendekatan yang bertujuan untuk mengetahui hubungan antara variabel dependen dan independen dengan mengambil data pada satu waktu tertentu secara bersamaan. Populasi dalam penelitian ini adalah penderita DM tipe 2 yang melakukan rawat jalan di Puskesmas Pademawu pada bulan Mei-Juni tahun 2017. Sampel dalam penelitian ini adalah sebagian pasien DM tipe 2 yang berobat jalan di Puskesmas Pademawu bulan Mei-Juni Pamekasan, Jawa Timur sebanyak 50 sampel. Kriteria inklusi yang digunakan adalah responden terdiagnosa DM tipe 2, lama menderita minimal 2 bulan, memiliki minimal satu anggota keluarga, dapat berkomunikasi verbal dengan baik, mampu membaca dan menulis, bersedia menjadi responden penelitian. Kriteria ekslusi adalah pasien yang mengalami komplikasi DM tipe 2 yang akut sehingga tidak memperkenankan untuk mengikuti penelitian.

Pengambilan sampel dalam penelitian ini yaitu menggunakan teknik simple random sampling yaitu menentukan sampel penelitian dengan memilih responden pasien DM tipe 2 yang berkunjung ke Puskesmas Pademawu sesuai metode undian secara acak sehingga sampel tersebut dapat mewakili karakteristik populasi yang telah diketahui sebelumnya. Berdasarkan hasil perhitungan sampel, didapatkan sampel sebanyak 50 responden.

Variabel penelitian berupa variabel bebas dan variabel terikat. Variabel bebas meliputi karakteristik responden (usia, jenis kelamin, tingkat pendidikan, lama menderita dan komplikasi DM), dukungan keluarga yang terdiri dari dimensi dukungan emosional, penghargaan, instrumental dan informasional. Dukungan keluarga diukur dengan kuesioner berdasarkan pedoman Sarafino yang terdiri dari 8 pertanyaan. Variabel terikat berupa kualitas hidup DM tipe 2 yang terdiri dari empat dimensi yaitu kepuasan DM, kekhawatiran pandangan sosial, kekhawatiran DM dan dampak dari DM. Variabel kualitas hidup DM tipe 2 diukur dengan menggunakan kuesioner Diabetes Quality of Life (DQOL) sebanyak 23 pertanyaan dengan pembagian berupa skala dampak, kepuasan. pandangan sosial dan pandangan terhadap penyakit DM tipe 2 .

Metode pengumpulan data dilakukan secara primer dan sekunder. Data primer berupa metode wawancara door to door kepada responden dengan berpedoman pada kuesioner terstruktur. Data sekunder didapatkan dari Puskesmas berupa profil Puskesmas Pademawu, distribusi DM Puskesmas Pademawu dari 3 tahun terakhir. Setelah data terkumpul maka dilakukan pengolahan data dengan tahapan editing, coding, entry dan cleaning data. Data kemudian dianalisis dengan analisis univariat dan bivariat. Analisis univariat 
dilakukan untuk memperoleh deskripsi karakteristik dari masing-masing variabel yang telah diteliti. Analisis univariat dapat berupa usia, jenis kelamin, tingkat pendidikan, lama menderita penyakit DM tipe 2, komplikasi yang dialami, dukungan keluarga serta kualitas hidup. Pada data numerik seperti data usia, lama penderita DM tipe 2, lama pengobatan, menggunakan nilai mean, standar deviasi kemudian untuk data kategorik seperti dukungan keluarga, jenis kelamin, tingkat pendidikan, dilakukan dengan menghitung persentase dari masing-masing kelompok selanjutnya maka diinterprestasikan dalam bentuk tabel. Analisis bivariat dilakukan untuk memperoleh apakah terdapat hubungan di antara dua variabel. Analisis bivariat digunakan untuk membuktikan hipotesis dari penelitian apakah ada hubungan antara dukungan keluarga dengan kualitas hidup pasien DM tipe 2. Uji statistik yang digunakan adalah chi-square dengan lanjutan uji Fisher dengan tingkat kemaknaan sebesar $5 \%(\alpha=0,05)$ dan kekuatan hubungan anatar dua variabel ditentukan dengan nilai Cramers' $V$.

\section{HASIL}

Penelitian dilakukan pada 50 orang penderita DM tipe 2 yang menjadi responden yang melakukan rawat jalan di Puskesmas Pademawu, Kabupaten Pamekasan. Data yang diambil meliputi karakteristik responden (usia, jenis kelamin, tingkat pendidikan, lama menderita dan komplikasi DM), dukungan keluarga, dan kualitas hidup DM tipe 2.

Variabel usia dibagi menjadi kategori umur dewasa $(<60$ tahun) dan lansia $(\geq 60$ tahun). Variabel tingkat pendidikan dikategorikan menjadi kategori rendah (tidak sekolah, SD dan SMP) dan tinggi (SMA dan PT/D3/D4). Variabel jenis kelamin dibagi menjadi dua kategori yaitu laki-laki dan perempuan. Variabel lama menderita dibagi menjadi kategori baru (penderita yang memiliki DM tipe 2 kurang dari tiga tahun) dan lama (penderita yang memiliki DM tipe 2 lebih dari sama dengan tiga tahun). Variabel komplikasi DM dibagi menjadi kategori ada dan tidak ada. Pada variabel ini juga dijelaskan komplikasi yang ada dapat berupa nefropati, neuropati, hipertensi, retinopati dan lainnya. Pada variabel dukungan keluarga dibagi menjadi kategori baik dan buruk. Pada kategori baik jika skor nilai lebih dari 2,5 (2,51-4,00) sedangkan kategori buruk jika skor kurang dari 2,5 (1,00-2,50). Variabel kualitas hidup dibagi menjadi kategori baik apabila skor 2,51-4,00 dan kategori buruk jika skor kurang dari 2,50 .
Tabel 1. Distribusi Karakteristik Responden Penelitian di Puskesmas Pademawu bulan Mei-Juni 2017

\begin{tabular}{|c|c|c|}
\hline Variabel & (n) & $\begin{array}{c}\text { Persentase } \\
(\%)\end{array}$ \\
\hline \multicolumn{3}{|l|}{ Usia } \\
\hline Dewasa & 23 & 46 \\
\hline Lansia & 27 & 54 \\
\hline \multicolumn{3}{|l|}{ Jenis Kelamin } \\
\hline Laki-laki & 8 & 16 \\
\hline Perempuan & 42 & 84 \\
\hline \multicolumn{3}{|l|}{ Tingkat Pendidikan } \\
\hline PT/D3/D4 & 2 & 4 \\
\hline SMA/MA & 8 & 16 \\
\hline SMP/MTS & 9 & 18 \\
\hline $\mathrm{SD}$ & 27 & 54 \\
\hline Tidak sekolah & 4 & 8 \\
\hline \multicolumn{3}{|l|}{ Komplikasi DM } \\
\hline Tidak Ada & 22 & 44 \\
\hline Ada & 28 & 56 \\
\hline \multicolumn{3}{|l|}{ Lama Menderita } \\
\hline Baru ( $\leq 3$ tahun) & 23 & 46 \\
\hline Lama (> 3 tahun) & 27 & 54 \\
\hline \multicolumn{3}{|l|}{ Dukungan Keluarga } \\
\hline Baik & 23 & 46 \\
\hline Buruk & 27 & 54 \\
\hline \multicolumn{3}{|l|}{ Kualitas Hidup } \\
\hline Baik & 24 & 48 \\
\hline Buruk & 26 & 52 \\
\hline
\end{tabular}

Tabel 1 menyatakan bahwa mayoritas responden memiliki usia dalam kategori lansia (lebih dari 60 tahun) sebesar $54 \%$, berjenis kelamin perempuan sebesar 84\%, memiliki tingkat pendidikan SD sebesar $54 \%$, mempunyai komplikasi (56\%), lama menderita lebih dari tiga tahun (54\%).

Tabel 2 menyatakan bahwa skor rata-rata variabel dukungan keluarga memiliki dukungan keluarga yang baik. Hal ini dikarenakan nilai rata-rata berada pada rentang 2,51-4,00 yang termasuk dalam kategori dukungan keluarga yang baik. Meskipun nilai ratarata dukungan keluarga sudah berada diatas 2,5 (nilai standar) namun nilai tersebut tidak cukup baik karena masih memiliki nilai sedikit diatas standar. Hal ini disebabkan selisih antara dukungan keluarga yang baik dengan dukungan keluarga yang buruk tidak memiliki jarak yang jauh (52\% dan $48 \%$ ). Dimensi emosional memiliki nilai rata-rata yang paling baik $(3,06)$ berbeda dengan nilai rata-rata dukungan informasional yang paling rendah $(1,64)$. Hal ini disebabkan sebesar $48 \%$ dan 50\% responden 
menyatakan keluarga mereka tidak pernah untuk memberikan informasi baru mengenai penyakit DM serta menyarankan penderita DM tipe 2 ke Posyandu Lansia terdekat.

Tabel 2. Distribusi Nilai Rata-Rata dan Standar Deviasi Dimensi Dukungan Keluarga di Puskesmas Pademawu Bulai Mei-Juni 2017

\begin{tabular}{ccc}
\hline Variabel & Mean & SD \\
\hline Dukungan Keluarga & 2,52 & 0,637
\end{tabular}

\section{Sub-variabel}

\begin{tabular}{lll} 
Dukungan Emosional & 3,06 & 0,468 \\
Dukungan Instrumental & 2,54 & 0,773 \\
Dukungan Penghargaan & 2,87 & 0,599 \\
Dukungan Informasi & 1,64 & 0,707 \\
\hline
\end{tabular}

Dukungan emosional memiliki nilai rata-rata tertinggi karena mayoritas responden sebesar $75 \%$ menyatakan bahwa keluarga penderita DM tipe 2 sering bersifat sukarela dan selalu merawat responden dengan kasih sayang dan 39 dari 50 responden juga menyatakan keluarga sering bersedia mendengar keluhan penderita DM tipe 2.

Dukungan informasional yang memiliki nilai ratarata yang rendah disebabkan sebesar $48 \%$ keluarga penderita DM tipe 2 tidak pernah memberikan informasi baru mengenai penyakit dan 50\% keluarga juga tidak pernah menyarankan responden ke posyandu lansia. Informasi yang terbatas bisa disebabkan sulitnya akses desa ke tempat pelayanan kesehatan terdekat (Puskesmas) sehingga banyak penderita DM tidak mengetahui mengenai posyandu lansia dan informasi lainnya.

Tabel 3. Distribusi Nilai Rata-rata dan Standar Deviasi Dimensi Kualitas Hidup DM tipe 2 di Puskesmas Pademawu Bulan MeiJuni 2017

\begin{tabular}{lcc}
\hline \multicolumn{1}{c}{ Variabel } & Mean & SD \\
\hline $\begin{array}{l}\text { Kualitas Hidup } \\
\text { Sub-variabel }\end{array}$ & 2,46 & $0,37-0,96$ \\
Kepuasan DM & 2,64 & $0,37-0,88$ \\
Pandangan Sosial & 2,57 & $0,61-0,96$ \\
Pandangan DM & 2,49 & $0,43-0,84$ \\
Dampak DM & 2,03 & $0,80-0,83$ \\
\hline
\end{tabular}

Tabel 3 menyatakan bahwa nilai rata-rata variabel kualitas hidup adalah 2,46 yang berarti masih berada di bawah standar nilai 2,50 sehingga masih berada dalam kategori buruk $(1,00-2,50)$. Di antara nilai subvariabel, nilai tertinggi adalah nilai rata-rata kepuasan DM yang sudah berada di atas nilai standar 2,50. Hal ini membuktikan bahwa aspek kepuasan DM umumnya sudah dalam kategori baik bagi penderita DM tipe 2 di Puskesmas Pademawu. Nilai rata-rata terendah adalah pada sub-variabel dampak DM yang masih berada pada nilai standar 2,5. Pernyataan aspek dampak DM dapat berupa gejala-gejala yang sering terjadi pada penderita DM tipe 2 seperti sering buang air kecil, sering nyeri, sulit untuk tidur, sering merasa kehausan sehingga pada aspek inilah yang memiliki pengaruh terkecil terhadap kualitas hidup DM tipe 2.

Di antara sub-variabel kepuasan hidup di dalam kuesioner DQOL, item pertanyaan yang memiliki skor terendah adalah pengetahuan yang dimiliki responden. Hal ini disebabkan karena sebanyak $62 \%$ responden masih menyatakan tidak puas terhadap pengetahuan akan diabetes tipe 2 terutama dalam hal pelaksanaan dan pengendalian kadar gula darah. Pada sub-variabel pandangan sosial, item pernyataan terendah adalah merasa takut berbeda dengan orang lain dengan nilai rata-rata 2,18 yang masih berada di bawah standar $(2,50)$. Hal ini disebabkan karena sebanyak $44 \%$ responden menyatakan sering mengalami perasaan berbeda dengan orang lain. Setiap kali diwawancarai, penderita merasa rendah diri akan penyakit DM terutama yang sudah mengalami komplikasi yang membuat penderita DM kurang percaya diri. Pada sub-variabel pandangan DM, item pernyataan takut mengalami keluhan akibat komplikasi merupakan item pernyataan dengan nilai rata-rata terendah dengan skor 2,04.

Hal ini disebabkankarena sebanyak $40 \%$ responden selalu merasa komplikasi adalah hal yang buruk sebab hal ini dapat memperlambat aktivitas seharihari penderita DM tipe 2 di wilayah Pademawu. Subvariabel dampak DM yang memiliki skor terendah adalah merasa sering buang air kecil dan nyeri pada malam hari yang masing-masing memiliki nilai ratarata 1,62. Hal ini disebabkan sebesar 50\% responden memiliki keluhan kedua gejala DM tersebut. Gejala DM yang paling mendasar umumnya adalah 3P (poliuri, polifagi, dan polidipsi).

Hasil penelitian didapatkan ada hubungan yang signifikan antara dukungan keluarga $(p=0,001)$, dan komplikasi DM $(0,011)$ dengan kualitas hidup DM tipe 2. Variabel umur, jenis kelamin, tingkat pendidikan, lama menderita tidak memiliki hubungan yang signifikan dengan kualitas hidup DM tipe 2. Hubungan antara dukungan keluarga (Cramer's V= 
Tabel 4. Hubungan antara Variabel Independen dengan Kualitas Hidup DM tipe $2(n=50)$ di Puskesmas Pademawu, Kabupaten Pamekasan Bulan Mei-Juni Tahun 2017

\begin{tabular}{|c|c|c|c|c|c|c|c|c|c|}
\hline \multirow{3}{*}{ Variabel Indepedent } & \multicolumn{4}{|c|}{ Kualitas Hidup } & \multicolumn{2}{|c|}{ Total } & \multirow{3}{*}{$95 \% \mathrm{Cl}$} & \multirow{3}{*}{$\begin{array}{c}p \\
\text { value }\end{array}$} & \multirow{3}{*}{ Cramers'V } \\
\hline & \multicolumn{2}{|c|}{ Baik } & \multicolumn{2}{|c|}{ Buruk } & \multirow{2}{*}{$\mathbf{n}$} & \multirow{2}{*}{$\%$} & & & \\
\hline & $\mathbf{n}$ & $\%$ & $\mathbf{n}$ & $\%$ & & & & & \\
\hline \multicolumn{10}{|l|}{ Dukungan Keluarga } \\
\hline Baik & 17 & 73,9 & 6 & 26,1 & 23 & 100 & $2,279-28,760$ & 0,001 & 0,479 \\
\hline Buruk & 7 & 25,9 & 20 & 74,1 & 27 & 100 & & & \\
\hline \multicolumn{10}{|l|}{ Usia } \\
\hline Dewasa & 12 & 52,2 & 11 & 47,8 & 23 & 100 & $0,447-4,163$ & 0,586 & 0,077 \\
\hline Lansia & 12 & 44,4 & 15 & 55,6 & 27 & 100 & & & \\
\hline \multicolumn{10}{|l|}{ Jenis Kelamin } \\
\hline Laki-laki & 4 & 50 & 4 & 50 & 8 & 100 & $0,242-4,991$ & 0,902 & 0,017 \\
\hline Perempuan & 20 & 47,6 & 22 & 52,4 & 42 & 100 & & & \\
\hline \multicolumn{10}{|l|}{ Tingkat Pendidikan } \\
\hline Tinggi & 4 & 40 & 6 & 60 & 10 & 100 & $0,163-2,727$ & 0,571 & 0,080 \\
\hline Rendah & 20 & 50 & 20 & 50 & 40 & 100 & & & \\
\hline \multicolumn{10}{|l|}{ Lama Menderita } \\
\hline Baru & 13 & 56,5 & 10 & 43,5 & 23 & 100 & $0,613-5.833$ & 0,266 & 0,157 \\
\hline Lama & 11 & 40,7 & 16 & 59,3 & 27 & 100 & & & \\
\hline \multicolumn{10}{|l|}{ Komplikasi } \\
\hline Tidak Ada & 15 & 68,2 & 7 & 31,8 & 22 & 100 & $1,366-14,981$ & 0,011 & 0,358 \\
\hline Ada & 9 & 32,1 & 19 & 67,9 & 28 & 100 & & & \\
\hline
\end{tabular}

0,479), kualitas hidup mempunyai kekuatan hubungan yang kategori cukup kuat sedangkan variabel usia (Cramer's $\mathrm{V}=0,077$ ), jenis kelamin (Cramer's $\mathrm{V}=$ 0,017), tingkat pendidikan (Cramer's $\mathrm{V}=0,080$ ), lama menderita (Cramer's $\mathrm{V}=0,157)$ dan komplikasi DM (Cramer's $\mathrm{V}=0,358)$ memiliki kekuatan hubungan yang sangat lemah (Tabel 4).

\section{PEMBAHASAN}

Usia adalah indikator untuk menentukan kedewasaan dalammelakukan pengambilan keputusan berdasarkan pengalaman. Pada tabel distribusi hasil penelitian didapatkan mayoritas usia responden berada pada kategori lansia atau lebih dari 60 tahun sebanyak 27 responden. Menurut Smeltzer dan Bare (2008), mayoritas penderita DM tipe 2 paling banyak dialami oleh orang-orang berada di usia 40 tahun ke atas. Hal ini disebabkan karena pada umur 40 tahun ke atas retensi insulin pada DM tipe 2 akan semakin meningkat di samping terdapat riwayat keturunan dan obesitas. WHO mengasumsikan bahwa setelah umur 30 tahun, maka kadar glukosa darah akan naik 1-2 $\mathrm{mg} / \mathrm{dL} /$ tahun sedangkan pada saat puasa akan naik 5,6-13 $\mathrm{mg} / \mathrm{dL}$ pada saat 2 jam setelah makan. Penelitian ini memiliki kesamaan dengan Sholikhah (2014), yang menyatakan bahwa semakin tinggi usia penderita DM tipe 2, maka akan semakin tinggi kadar glukosa darah yang disebabkan gangguan toleransi glukosa. Hasil uji statistik menggunakan chi square menyatakan tidak ada hubungan antara usia dengan kualitas hidup DM tipe 2. Hal ini tidak sesuai dengan penelitian Utami (2014), yang didalamnya yang menyatakan ada hubungan usia dengan kualitas hidup DM. Penelitian ini juga memiliki hasil yang berbeda dengan Yusra (2010), mengasumsikan bahwa secara normal semakin bertambah usia seseorang maka akan sering terjadi penurunan atau perubahan dari segi fisik, intelektual dan psikologis.

DM merupakan penyakit yang sering muncul akibat kegagalan metabolis semakin bertambahnya usia, sehingga semakin tinggi usia seseorang, semakin rentan terkena DM dan akan berujung pada kualitas hidup seseorang. Retnowati (2015), menyimpulkan kualitas hidup penderita DM tipe 2 lebih dipengaruhi oleh kondisi kronis seperti komplikasi sebagai variabel perancu utama daripada keadaan sosiodemografi (usia, jenis kelamin atau penghasilan). 
Penderita DM tipe 2 yang dapat mencegah timbulnya komplikasi diyakini mampu hidup lebih lama sampai usia tua sehingga kualitas hidupnya tetap baik. Hal yang menyebabkan pada penelitian ini menyatakan tidak ada hubungan antara usia dengan kualitas hidup DM tipe 2 adalah responden yang berusia lebih atau kurang dari 60 tahun, memiliki persentase yang hampir sama untuk memiliki kualitas hidup yang buruk yaitu $47,8 \%$ dan $55,6 \%$.

Mayoritas responden penelitian memiliki jenis kelamin perempuan yaitu sebesar $90 \%$. Hal ini sesuai dengan pernyataan Taylor (2010), yang menyatakan bahwa penyebab utama banyaknya perempuan terkena diabetes tipe 2 karena terjadinya penurunan hormon estrogen terutama saat masa menopause. Hormon estrogen dan progesteron memiliki kemampuan untuk meningkatkan respons insulin di dalam darah. Pada saat masa menopause terjadi, maka respons akan insulin menurun akibat hormon estrogen dan progesteron yang rendah. Faktor-faktor lain yang berpengaruh adalah body massa index perempuan yang sering tidak ideal sehingga hal ini dapat menurunkan sensitivitas respons insulin. Hal inilah yang membuat wanita sering terkena diabetes daripada laki-laki.

Hasil uji statistik dengan chi-square menyatakan nilai tidak ada hubungan signifikan antara jenis kelamin dengan kualitas hidup penderita DM tipe 2. Hal ini ditandai jenis kelamin laki-laki maupun perempuan memiliki nilai persentase $50 \%$ dan $52 \%$ untuk kualitas hidup buruk. Penelitian ini memiliki hasil yang berbeda dengan Saputro (2008), dan Herdianti (2017), yang menyatakan ada hubungan antara jenis kelamin dengan kualitas hidup DM tipe 2 dan perempuan diyakini memiliki kualitas hidup yang lebih rendah daripada laki-laki.

Hal yang memungkinkan berbeda dalam hal hasil disebabkan responden sebagian besar adalah perempuan dan baik perempuan dan laki-laki hampir sama dalam memiliki risiko kualitas hidupnya dalam memahami pengetahuan yang mereka peroleh. Hasil penelitian ini sejenis dengan penelitian Ningtyas (2013), dan Retnowati (2015), yang menyatakan tidak ada hubungan antara jenis kelamin dengan kualitas hidup penderita DM tipe 2. Faktor-faktor lain yang lebih berkontribusi terhadap kualitas hidup DM tipe 2 seperti menurut Tandra (2008), penyakit penyerta ataupun komplikasi seperti pada laki-laki yang terkena diabetes dapat mengakibatkan terjadinya impotensi sedangkan pada perempuan dapat menimbulkan infeksi vagina sehingga risiko keparahan pada jenis kelamin ini sama dan berpengaruh pada kualitas hidupnya. Yusra (2011), juga menyampaikan bahwa faktor kepatuhan dalam meminum obat merupakan faktor yang berkontribusi dalam kualitas hidup.

Kepatuhan umumnya dimiliki oleh perempuan sehingga pelaksanaan pengobatan dapat berjalan dengan baik. Namun, laki-laki cenderung memiliki kepercayaan yang lebih tinggi , bersikap mandiri, dan selalu bersikap positif terhadap penyakitnya. Oleh karena itu, laki-laki dan perempuan umumnya memiliki kemampuan yang sama untuk menyelesaikan masalahnya (dalam hal ini penyakit)/koping sehingga berdasarkan hal tersebut perbedaan jenis kelamin tidak memengaruhi kualitas hidup DM tipe 2. Tingkat pendidikan juga memengaruhi matangnya perubahan diri seseorang untuk menerima pengaruh luar yang positif terkait dengan informasi kesehatan sehingga dengan mudahnya penerimaan informasi tersebut, akan memudahkan penderita DM tipe 2 melakukan manajemen perawatan.

Mayoritas responden memiliki tingkat pendidikan rendah yaitu sekitar $80 \%$ (40 responden). Pendidikan rendah ini terdiri dari golongan tidak sekolah, SD, dan SMP. Responden penderita DM di wilayah Puskesmas Pademawu mayoritas juga memiliki pendidikan tamat SD yaitu 54\% (27 responden). Hal ini memiliki kesamaan dengan penelitian Tamara dkk (2014) yang menyatakan mayoritas responden masih berada di tingkat pendidikan yang rendah.

Hasil analisis dengan menggunakan uji statistik chi-square menghasilkan pernyataan tidak terdapat hubungan signifikan antara tingkat pendidikan dengan kualitas hidup penderita DM tipe 2. Hal ini disebabkan karena responden terbanyak adalah masyarakat terutama lansia desa Pademawu di mana terkadang pendidikan bukan merupakan hal yang prioritas, bahkan berdasarkan hasil wawancara dengan penduduk setempat, masyarakat pada zaman dahulu hanya bisa mengenyam pendidikan sampai SD (Sekolah Dasar). Penelitian ini memiliki hasil yang berbeda dengan penelitian milik Ningtyas (2014), serta Retnowati (2015), yang menyatakan ada hubungan antara tingkat pendidikan dengan kualitas hidup DM tipe 2. Menurut penelitian Retnowati (2015), menghasilkan $p$ value 0,039 sehingga terdapat hubungan antara tingkat pendidikan dengan kualitas hidup penderita DM tipe 2.

Pendidikan diyakini sebagai faktor penting untuk memahami manajemen, kepatuhan kontrol gula darah, mengatasi gejala yang muncul dengan penanganan yang tepat serta mencegah terjadinya komplikasi Pendidikan umumnya terkait dengan pengetahuan. Penderita dengan pendidikan tinggi 
memiliki pengetahuan lebih baik mengenai penyakit diabetes dan efeknya terhadap kesehatan sehingga penderita akan menyikapi dengan positif serta akan berusaha (Javanbakht, et al., 2012). Namun, meskipun pendidikan seseorang tinggi, tidak menjamin bahwa pengalaman yang didapat juga akan tinggi sebab hal ini juga dipengaruhi oleh faktor sosial budaya yang dapat memengaruhi seseorang untuk melakukan tindakan berdasarkan pengalamannya. Adat-istiadat, norma, dorongan dari orang-orang terdekat merupakan salah satu faktor yang membuat seseorang melakukan pengambilan keputusan untuk bertindak.

Mayoritas responden juga sudah mempunyai penyakit DM selama lebih dari 3 tahun yaitu 27 responden (54\%). Hal ini sesuai dengan pernyataan Rahmat (2010), yang menyebutkan bahwa pada penderita DM tipe 2 sering terjadi penurunan kualitas setelah penderita DM selama satu tahun. Hal ini diakibatkan setelah satu tahun, akan terjadi perubahan psikis dan fisik selama menderita DM tipe 2 .

Mayoritas responden DM memang lebih banyak menderita lebih dari 3 tahun, namun berdasarkan uji statistik dengan chi-square menghasilkan pernyataan tidak ada hubungan signifikan antara lama menderita dengan kualitas hidup DM tipe 2 di Puskesmas Pademawu. Hal ini bisa disebabkan karena lama menderita DM masih dalam kurun waktu yang singkat, namun jika disertai dengan komplikasi yang cepat, baik itu jangka yang pendek ataupun panjang, maka hal itu berpengaruh pada penurunan kualitas hidup penderita.

Hasil penelitian ini sejalan dengan Donald et al. (2013), dengan menyatakan bahwa lama menderita tidak berhubungan secara signifikan dengan kualitas hidup penderita DM tipe 2. Yusra (2011), juga mengatakan pernyataan yang sama dengan melihat bahwa penderita yang telah lama menderita DM namun juga disertai komplikasi memiliki efikasi yang rendah. Peningkatan kualitas hidup diasumsikan dapat terjadi jika terdapat manajemen perawatan yang dilaksanakan dengan benar sehingga menjaga kadar gula darah tetap stabil. Penelitian ini tidak sejalan dengan Ningtyas (2014), yang sehingga ada hubungan yang signifikan antara lama menderita dengan kualitas hidup DM tipe 2 dengan nilai risiko 3,8 kali lebih besar kualitas hidup yang buruk pada penderita DM tipe 2 yang memiliki dukungan keluarga yang kurang.

Perbedaannya penelitian lain dengan penelitian ini adalah pada penelitian Ningtyas menggunakan pembagian durasi yang lebih lama (lama menderita kurang atau lebih 10 tahun) berbeda dengan penelitian ini yang hanya dalam durasi kurang lebih 3 tahun. Yusra (2011), menyatakan pasien yang telah menderita DM lebih dari 11 tahun memiliki efikasi diri yang lebih daripada pasien yang menderita DM kurang dari 10 tahun. Hal ini disebabkan pasien yang telah menderita DM lebih panjang, akan lebih berpengalaman dalam mengelola penyakitnya sehingga memiliki koping yang lebih baik. Kedua pendapat dari penelitian sebelumnya memang berbeda, namun pada intinya kualitas hidup tidak hanya dipengaruhi oleh lama menderita saja namun juga faktor-faktor lain seperti tingkat pendapatan. pendidikan, pengalaman sosial budaya yang dapat memengaruhi seseorang untuk melakukan tindakan pengobatan dan perawatan DM tipe 2 yang dapat meningkatkan kualitas hidup.

Hasil penelitian didapatkan mayoritas responden memiliki komplikasi sebesar 56\% (28 responden). Penyakit DM tipe 2 merupakan penyakit yang dapat mengakibatkan munculnya penyakit lain. Komplikasi DM tipe 2 dapat berupa hipertensi, PJK, neuropati (gangguan saraf), retinopati (gangguan pada mata), nefropati (gangguan pada ginjal), kulit, dll. Mayoritas responden dalam penelitian menderita komplikasi hipertensi sebesar 30\%, PJK, retinopati dan stroke yang masing-masing $6 \%$ dan komplikasi lainnya seperti gangren, neuropati sebesar $2 \%$.

Hipertensi merupakan salah satu komplikasi yang sering mengiringi penyakit DM tipe 2. Prabawati (2012) menyatakan penderita DM tipe 2 ditemukan kondisi resistensi insulin. Resistensi insulin ini dapat mengakibatkan hormon insulin tidak dapat mengubah glukosa menjadi lebih sederhana di dalam darah sehingga hal ini dapat meningkatkan tekanan darah di dalam tubuh. Fungsi hormon insulin selain bekerja untuk mengubah glukosa menjadi glikogen namun juga dapat meningkatkan retensi natrium di dalam ginjal dan meningkatkan aktivitas syaraf simpatik. Kedua fungsi merupakan hal yang berpengaruh terhadap meningkatkan tekanan darah. Hasil penelitian ini sesuai dengan penelitian Tamara (2014), yang menyatakan bahwa sebesar 45,9\% yang memiliki hipertensi juga menderita DM tipe 2. Penelitian dengan hasil yang sama juga terdapat pada Restada (2016), bahwa terdapat 46,7\% responden menderita hipertensi, penelitian Jelantik dan Haryati (2014), yang juga menunjukkan bahwa 44 responden dari 50 responden mengalami hipertensi ketika menderita DM tipe 2.

Hasil uji statistik dengan menggunakan chi-square didapatkan pernyataan ada hubungan antara komplikasi dengan kualitas hidup DM tipe 2 di Puskesmas Pademawu. Hasil penelitian ini sejalan 
dengan Ningtyas (2013), yang menyatakan bahwa ada hubungan yang signifikan antara komplikasi dengan kualitas hidup dengan $\mathrm{OR}=10,7$ sehingga penderita DM tipe 2 yang memiliki komplikasi memiliki risiko 11 kali lebih besar mempunyai kualitas hidup yang buruk daripada penderita yang tidak memiliki komplikasi. Penelitian ini juga sejalan dengan penelitian Retnowati (2015) yang menyatakan komplikasi merupakan faktor perancu penentu utama penentu kualitas hidup DM. Maatouk et al (2012), menyatakan komplikasi DM merupakan faktor penentu terkuat terhadap kualitas hidup pasien DM selama 5 tahun ke depan. Penelitian lain yang sejenis adalah Yusra (2011) yang menyatakan bahwa komplikasi yang telah dialami penderita DM dapat mengakibatkan adanya keterbatasan baik segi fisik, psikologis dan sosial yang juga akan berdampak terhadap kualitas hidup.

Donald et al (2013), menyatakan komplikasi DM akan mengakibatkan komplikasi fisik seperti hipertensi, gangren, katarak, obesitas, kehilangan berat badan dan gangguan seksual yang akan menurunkan kualitas hidup. Selain menyerang dari segi fisik, namun juga mengakibatkan kerusakan pada mental. Hal ini terjadi disebabkan penderita terkadang memiliki depresi, rasa gelisah dan skizofrenia yang menyebabkan turunnya kualitas hidup. Selama penelitian berlangsung dengan responden di desa Pademawu, terdapat 1-3 responden yang telah mengalami komplikasi yang sangat parah, terdapat gangren di kulit kaki yang bahkan membusuk sehingga menyebabkan responden/pasien DM tersebut tidak dapat berjalan. Ada juga pasien yang telah mengalami amputasi pada kaki akibat gangren kulit yang parah sehingga terpaksa kehilangan jari-jari kakinya. Pasien yang mengalami komplikasi yang parah ini selalu mengeluh mengenai dirinya yang tak mampu melakukan aktivitas seperti biasa bahkan terkadang terdapat pasien yang merasa tidak berguna dan selalu berkecil hati. Perasaan cemas yang berlebihan akan mengakibatkan imunitas pasien semakin menurun dan berakibat langsung terhadap kualitas hidup.

Mayoritas responden memiliki dukungan keluarga yang buruk yaitu sebesar 27 dari 50 responden (54\%). Banyak faktor yang dapat menyebabkan dukungan keluarga memiliki kategoriyang berbeda tiap penderita DM tipe 2. Faktor yang memengaruhi dapat berupa tingkat sosial ekonomi seperti tingkat pendapatan. Pada keluarga kelas menengah, hubungan yang lebih demokratis dan adil mungkin ada, namun pada keluarga menengah ke bawah, hubungan yang ada lebih bersifat otoritas. Faktor lain yang berpengaruh adalah tingkat pendidikan, semakin tinggi tingkat pendidikan keluarga maka diasumsikan semakin besar pengalaman dalam memberikan dukungan pada anggota keluarga yang sakit. Hal ini sesuai hasil penelitianyang sebagianmenyebutkanbahwasebagian besar keluarga di wilayah Puskesmas Pademawu masih berpendapatan rendah dan pekerjaan seharihari adalah menjadi buruh tani. Tingkat pendidikan keluarga penderita DM umumnya masih rendah dan mayoritas memiliki pendidikan tamat SMA sehingga kurangnya pengalaman akan pengendalian dan perawatan penyakit DM menyebabkan dukungan keluarga masih belum cukup baik.

Penilaian dukungan keluarga ini berdasarkan empat dimensi yaitu dimensi emosional, dimensi instrumental, dimensi penghargaan dan dimensi informasional. Setiap dimensi memiliki pertanyaan yang berbeda-beda. Nilai rata-rata dimensi emosional adalah 3,015, dimensi instrumental sebesar 2,54, dimensi penghargaan sebesar 2,87 dan dimensi informasional sebesar 1,64. Sehingga di antara keempat dimensi tersebut, nilai skor rata-rata terendah adalah dimensi informasional. Hal ini dapat dibuktikan ketika setiap kali wawancara, banyak responden yang masih belum tahu mengenai penyakit DM secara mendasar dan belum tahunya masyarakat akan adanya posyandu lansia di Puskesmas. Masyarakat masih banyak yang lebih percaya akan khasiat jamu (pengobatan tradisional) daripada penanganan dokter sehingga pemberian informasi ini perlu dilakukan kembali oleh petugas Puskesmas.

Dimensi lain yang memiliki skor rendah adalah dimensi instrumental. Dimensi instrumental ini berupa dukungan keluarga terkait pemeriksaan darah, pengobatan secara teratur serta pengaturan pola makan. Banyak responden ketika dilakukan wawancara mengaku jarang melakukan cek darah secara teratur dan hanya melakukan cek darah ketika sakit. Pada penderita DM tipe 2 sebaiknya sering melakukan pengecekan darah minimal satu bulan sekali. Di beberapa wilayah menyatakan bahwa pemeriksaan darah dikenai biaya padahal Puskesmas saat ini melakukan pemeriksaan darah tanpa dipungut biaya. Dalam hal pengobatan mendapat masalah yang sama, responden jarang untuk minum obat dan meskipun telah minum obat, masyarakat akan berhenti jika sudah sembuh. Pada hakikatnya pengobatan farmakologis DM tipe 2 bersifat berkelanjutan sepanjang umur. Rendahnya dukungan instrumental ini dapat disebabkan oleh tingkat pendidikan dan pengalaman masyarakat yang menyepelekan kunjungan rutin untuk cek darah ataupun tingkat 
pendapatan penduduk yang berbeda sehingga hal ini membuat penderita DM tipe 2 tidak membeli obat secara rutin. Sedangkan dimensi emosional memiliki nilai rata-rata yang sangat baik.

Hal ini disebabkan lebih dari $78 \%$ keluarga telah menyatakan telah menerima dengan sukarela terhadap keadaan penderita DM tipe 2. Penelitian ini sejalan dengan Luthfa (2016) yang menyatakan dukungan emosional merupakan dimensi yang mudah didapatkan dalam keluarga. Penerimaan keluarga pada kondisi apapun merupakan dukungan emosional yang sangat penting dan termasuk dalam fungsi afektif keluarga. Dukungan emosional ini akan membuat penderita DM tipe 2 untuk selalu waspada dan mengendalikan emosi terhadap komplikasi yang ada serta dapat mengurangi perasaan rendah diri terhadap kondisi keterbatasan fisik yang dialami.

Hasil uji statistik menyebutkan terdapat hubungan dukungan keluarga dengan kualitas hidup DM tipe 2. Hal ini ditandai responden yang memiliki dukungan keluarga yang baik dengan kualitas hidup baik terdapat 17 responden $(73,9 \%)$ daripada responden dengan dukungan keluarga baik namun kualitas buruk $(26,1 \%)$ sehingga dapat disimpulkan semakin baik dukungan keluarga penderita DM maka semakin baik pula nilai kualitas hidupnya. Hasil penelitian ini sejalan dengan Tamara (2014) yang menghasilkan penelitian dengan $p$ value $=0,03$.

Dukungan keluarga diyakini sangat membantu pasien DM tipe 2 dalam melakukan tindakan perawatan seperti pengecekan gula darah secara teratur dan minum obat. Pasien DM tipe 2 yang selalu diperhatikan oleh anggota keluarganya akan menciptakan rasa nyaman dan aman sehingga dapat meningkatkan motivasi pasien untuk sembuh. Jika rasa nyaman dan aman tercipta maka akan terhindar dari perasaan gelisah dan stress yang diyakini merupakan penyebab kualitas hidup pasien menurun. Dukungan keluarga juga memiliki pengaruh terhadap kualitas hidup penderita DM. Keluarga merupakan bagian penting dari seseorang begitu pula dengan penderita DM.

Penderita DM tipe 2 tentunya memiliki masa-masa sulit seperti berbenah diri, sering mengontrol gula darah, pola makan, dan aktivitas. Tentu saja segala hal ini membutuhkan bantuan atau dukungan dari orang sekitar terutama keluarga. Penderita diabetes yang sering menceritakan segala kondisi dengan orang terdekat, maka diharapkan membantu dalam kontrol diet, kecemasan, pengobatan serta dapat meningkatkan kualitas hidup penderita diabetes. Herdianti (2017), juga menyatakan penderita DM tipe 2 yang mendapat dukungan keluarga yang kurang memiliki risiko 5,14 kali kualitas hidup yang buruk daripada penderita DM tipe yang memiliki dukungan keluarga yang baik. Dukungan keluarga diyakini sangat membantu pasien DM tipe 2 dalam melakukan tindakan perawatan seperti pengecekan cek gula darah secara teratur dan minum obat. Penelitian sama yang lain adalah Retnowati (2015), yang menghasilkan $p$ value $=0,000$ sehingga dukungan keluarga memiliki hubungan dengan kualitas hidup penderita DM tipe 2. Semakin tinggi dukungan yang diperoleh maka semakin rendah derajat depresi yang dialami penderita DM sehingga kualitas hidupnya akan semakin tinggi, begitu pula sebaliknya. Dukungan keluarga mempunyai dampak terhadap kesehatan fisik dan mental anggota keluarga yang menderita DM.

Dukungan keluarga dapat meningkatkan kesehatan dan mengurangi depresi pada penderita diabetes hingga akhirnya dapat meningkatkan kualitas hidup penderita DM. Pasien merasakan dukungan sosial dari keluarga merupakan faktor psikososial penting yang dapat memengaruhi kontrol glikemik pada pasien dengan diabetes tipe 2 selain pasien dengan diabetes tipe 1. Motivasi keluarga dalam peningkatan kualitas hidup bagi pasien diabetes tipe 2 sangat besar pengaruhnya, maka dari pihak medis dan paramedis yang terkait selalu mendukung keluarga untuk terus mendekatkan diri kepada pasien termasuk dalam mengatur jadwal rutin cek gula darah.

\section{SIMPULAN DAN SARAN}

\section{Simpulan}

Pada penelitian didapatkan kesimpulan bahwa mayoritas responden memiliki usia dalam kategori lansia (lebih dari 60 tahun), berjenis kelamin perempuan, memiliki tingkat pendidikan rendah dengan pendidikan yang ditempuh SD, mempunyai komplikasi dengan persentase terbanyak adalah hipertensi, lama menderita lebih dari tiga tahun, dan dukungan keluarga yang buruk. Tidak ada hubungan yang signifikan antara usia, jenis kelamin, tingkat pendidikan, lama menderita dengan kualitas hidup DM tipe 2 di Puskesmas Pademawu, Kabupaten Pamekasan.

Variabel yang memiliki hubungan yang signifikan adalah komplikasi yang diduga berpengaruh terhadap kesehatan mental dan fisik penderita DM tipe 2, dukungan keluarga yang diyakini dapat meningkatkan rasa nyaman dan aman sehingga dapat meningkatkan motivasi pasien untuk sembuh. Dukungan keluarga umumnya terdiri dari empat dimensi yaitu 
dimensi emosional, dimensi instrumental, dimensi penghargaan dan dimensi informasional. Di antara keempat dimensi ini, dimensi informasional yang perlu diperhatikan sebab masih banyak penderita DM tipe di wilayah Puskesmas Pademawu yang masih belum mengetahui secara benar pelaksanaan dan pengendalian DM tipe 2 serta kurangnya kesadaran anggota keluarga untuk memberikan informasi baru mengenai penyakit DM tipe 2 .

\section{Saran}

Bagi masyarakat terutama pada penderita DM tipe 2 hendaknya selalu menjaga kadar gulanya agar tetap normal sehingga tidak terjadi komplikasi yang meningkatkan kesakitan atau keparahan. Masyarakat hendaknya juga rajin meluangkan waktu untuk melakukan aktivitas fisik baik di dalam dan di luar rumah sehingga dapat menurunkan kadar gula dalam darah. Selain melakukan aktivitas fisik, penderita DM tipe 2 hendaknya juga selalu meminum obat secara teratur untuk menurunkan risiko komplikasi.

Bagi keluarga penderita DM tipe 2 semakin meningkatkan kesadaran dalam merawat penderita DM tipe 2 baik itu dukungan secara emosional maupun secara langsung sehingga dapat meningkatkan motivasi penderita untuk sembuh (misalnya rajin untuk mengingatkan pengecekan darah). Keluarga dan penderita juga lebih sering untuk mengikuti program-program posyandu lansia atau edukasi diabetes sehingga dapat informasi baru mengenai pengendalian dan perawatan terkait diabetes tipe 2 . Keluarga juga selalu memberi kesempatan kepada penderita untuk berkomunikasi dan mendengarkan keluhan penderita DM agar dapat memberikan perlakuan yang tepat.

Puskesmas Pademawu sebagai institusi pemberi pelayanan kesehatan hendaknya semakin meningkatkan promosi program edukasi diabetes terutama mengenai pentingnya dukungan keluarga dan aktivitas fisik ke seluruh wilayah Pademawu. Program ini tidak hanya ditujukan kepada penderita DM tipe 2, namun juga mencakup keluarga untuk menyamakan persepsi penatalaksanaan DM tipe 2. Puskesmas Pademawu hendaknya tidak hanya mengadakan posyandu lansia di Puskesmas saja namun juga dapat dilakukan di setiap dusun dengan memberdayakan kader yang telah ada.

Perlunya pengawasan dan evaluasi lebih lanjut baik dari program posyandu lansia dengan memberikan tambahan olahraga bersama setiap pagi dan pengecekan gratis dengan melibatkan kerja sama lintas sektoral seperti Dinkes dan pemerintah
Kabupaten Pamekasan. Puskesmas juga sebaiknya melakukan pemeriksaan kembali berdasarkan daftar penderita DM di wilayah Pademawu tidak hanya dari rawat inap dan rawat jalan, namun juga berasal dari rumah sakit agar dapat diketahui distribusi prevalensi dan insiden penderita DM tipe 2 yang benar.

Penelitian ini hendaknya lebih dikembangkan lagi terutama mencari variabel perancu yang bisa memengaruhi variabel dependen kualitas hidup DM tipe 2. Selain mencari variabel perancu, penelitian dengan menganalisis lebih spesifik dari variabel dukungan keluarga juga diperlukan terutama mencari hubungan antara masing-masing dimensi dukungan keluarga seperti dimensi emosional. instrumental, penghargaan dan informasional dengan kualitas hidup DM tipe 2. Penelitian juga memiliki keterbatasan terutama dalam hal wawancara kepada responden yang memiliki tingkat pemahaman yang berbedabeda sehingga tidak jarang peneliti harus memberikan penjelasan ulang agar responden mengerti. Hal yang bisa memengaruhi dalam wawancara adalah ada tidaknya anggota keluarga pada saat diwawancarai. Anggota keluarga terkadang juga turut menjawab pertanyaan yang diberikan peneliti sehingga dapat memengaruhi jawaban penderita DM tipe 2 .

\section{REFERENSI}

Donald, M., Dower, J., Coll, J.R., Baker, P., Mukandi, B. \& Doi, S.A.R. 2013. Mental health issues decrease diabetes-specific quality of life independent of glycaemic control and complications: findings from Australia's living with diabetes cohort study. Health and Quality of Life Outcomes, 11(170), pp. 1-8. Tersedia di: https://hqlo.biomedcentral.com/ articles/10.11 86/1477-7525-11-170 [Sitasi 19 Juli 2017].

Herdianti, H. 2017. Determinan Kualitas Hidup Penderita DM Tipe 2 di RSUD Ajjappange. Journal Endurance. Vol 29(1) Februari 2017 7480. Tersedia di: ejournal.kopertis10.or.id/index. php/endurance/article/download/1662/567. [Sitasi 19 Juli 2017].

International Diabetes Federation. 2013. Diabetes Atlas: Impact on The Individual, [pdf], Tersedia di:http://da3.diabetesatlas.org/index 68fc. html, [Sitasi 2 Desember 2016].

Javanbakht, M., Abolhasani, F., Mashayekhi, A., Baradaran, H.R. \& Noudeh, Y.J. 2012. Health Related Quality of Life in Patients with Type 2 Diabetes Mellitus in Iran: A National Survey. Plos One, 7(8), pp. 1-9. Tersedia di: http://journals. 
plos.org/plosone/article?id=10.1371/journal. pone.0044526 [Sitasi 13 Mei 2017].

Larasati, T.A. 2012. Kualitas Hidup Pasien Diabetes Melitus Tipe 2 di RS Abdul Moeloek Propinsi Lampung. Jurnal Kedokteran dan Kesehatan Universitas Lampung, Vol.2, No.2, 17-20. [e-journal] Tersedia di: http://juke.kedokteran. unila.ac.id/index.php/juke/article/view/4 [Sitasi pada tanggal 26 Desember 2016].

Luthfa, I. 2016. Family Support pada Penderita Diabetes Mellitus Tipe 2 di Puskesmas Bangetayu Semarang, Analisis Rasch Model. Jurnal Keperawatan dan Pemikiran Ilmiah, Vol. 2(2): 1-7. Tersedia di: jurnal.unissula.ac.id/index.php/ jnm/article/download/723/602 [Sitasi pada tanggal 5 Juli 2017].

Maatouk, I., WildF, B., Wesche, D., Herzog, W., Raum, E. \& Muller, H. 2012. Temporal Predictors People with Diabetes: Results of a German Cohort Study. Plos One, 7(1), pp. 1-7. Tersedia di: http:// journals.plos.org/plosone/article/file?id=10.1371/ journal.pone.0031088\&type $=$ printable [Sitasi 18 Juli 2017].

Ningtyas, D.W. 2013. Analisis Kualitas Hidup Pasien Diabetes Melitus Tipe II di RSUD Bangil Kabupaten Pasuruan. Artikel Ilmiah Hasil Penelitian Mahasiswa 2013. Tersedia di repository. unej.ac.id/handle/ 123456789/1751 [Sitasi 11 Juni 2017].

Meidikayanti, W. 2017. Hubungan Dukungan Keluarga dan Aktivitas Fisik dengan Kualitas Hidup DM Tipe 2, Studi Cross-Sectional di Puskesmas Pademawu, Kabupaten Pamekasan. Skripsi . Surabaya: Fakultas Kesehatan Masyarakat Universitas Airlangga.

Noviarini, P.D., Prabowo, H. 2013. Hubungan antara Dukungan keluarga dengan Kualitas Hidup pada Pecandu Narkoba yang sedang menjalani Rehabilitasi. Jurnal Psikologi 5(1): pp. 116-122. Tersedia di: <ejournal.gunadarma.ac.id/inex.php/ pesat/iss u eview/119> [Sitasi pada tanggal 26 Desember 2016].

Pertiwi, N. 2013. Hubungan Lama Menderita Diabetes Mellitus dengan Kualitas Hidup DM tipe 2 di Poliklinik Penyakit Dalam RSUD Panembahan Senopati Bantul. Tersedia di https://www. scribd.com/doc/239895679/Hubungan-LamaMenderita-Diabetes-Melitus-Dengan-KualitasHidup [Sitasi 19 Juli 2017].

Prabawati, R.K. 2012. Mekanisme Seluler dan Molekuler Resistensi Insulin. Artikel Ilmiah. Tersedia di: http://aulanni.lecture.ub.ac.id/ files/2012/04/resistensi-insulin-dr-risma.pdf [Sitasi tanggal 19 Juli 2017].

Rachmaningtyas, A. 2013. Data SDKI 2012, Angka Kematian Ibu Melonjak. Tersedia di: $<$ http://nasional.sindonews.com/read/2013 /09/25/15/787480 /data-sdki-2012- angkakematian-ibu-melonjak>, [Sitasi pada tanggal 26 Desember 2016].

Rahmat, W.P. 2010. Pengaruh konseling terhadap kecemasan dan kualitas hidup pasien DM di Kecamatan Kebakkramat. Tesis. Tersedia di eprints.uns.ac.id [Sitasi pada tanggal 20 Desember 2013].

Retnowati, N. 2015. Hubungan Dukungan Keluarga dengan Kualitas Hidup Penderita Diabetes Melitus di Puskesmas Tanah Kalikedinding. Jurnal Berkala Epidemiologi Vol. 3 No. 1 Januari 2015 57-68 Tersedia di: e-journal.unair.ac.id/index.php/ JBE/article/download/1314/1073 [Sitasi 21 April 2017].

Restada, E.J. 2016. Hubungan Lama Menderita dan Komplikasi Diabetes Melitus dengan Kualitas Hidup Pada Penderita Diabetes Melitus di Wilayah Puskesmas Gatak Sukoharjo. Skripsi. FIK UMS. Tersedia di: eprints.ums.ac.id/45383/1/ NASKAH\%20PUBLIKASI.pdf [Sitasi 11 Juni 2017].

Saputro, A.A. 2008. Evaluasi Kualitas Hidup Pasien Diabetes Melitus Tipe 2 Rawat Jalan di RSUD Wirosaban Yogyakarta. Skripsi. Yogyakarta: Universitas Islam Indonesia.

Sholikhah, W.S. 2014. Hubungan Antara Usia, Indeks Massa Tubuh Dan Tekanan Darah Dengan Kadar Gula Darah Pada Lansia Di Desa Baturan Kecamatan Colomadu. Artikel Publikasi Ilmiah. FIK UMS. Tersedia di http://eprints.ums. ac.id/32167/13/NASKAH\%20PUBLIKASI.pdf [Sitasi 19 Juli 2017].

Smeltzer, S., Bare. 2008. Brunner and suddarth"s textbook of medical surgical nursing. Philadelpia: Lippincott.

Tamara, E., Bayhakki,, Fathra, A.N. 2014. Hubungan antara Dukungan Keluarga dan Kualitas Hidup Pasien Diabetes Mellitus Tipe II di RSUD Arifin Achmad Provinsi Riau. JOM PSIK. Vol. 1 No. 2. 22 Juni 2017.Tersedia di TNR.

Taylor, C., Lillis, C., Lemone, P., \& Lynn, P. 2010. Fundamental of nursing: The Art and Science of Nursing Care ( $\left.7^{\text {th }}\right)$. Philadelphia: Lippincott Williams \& Wilkins.

Utami, Ni Made, S.N. 2013. Hubungan antara Dukungan Keluarga dengan Penerimaan Diri 
Individu yang Mengalami Asma. Jurnal Psikologi Udayana. Vol. 1, 12-21. Tersedia di: https:// ojs.unud.ac.id/index.php/psikologi/article/ view/25044/16260. [Sitasi 11 Juni 2017].

Yusra, A. 2011. Hubungan antara Dukungan Keluarga dengan Kualitas Hidup Pasien Diabetes Melitus
Tipe 2 di Poliklinik Penyakit Dalam Rumah Sakit Umum Pusat Fatmawati Jakarta. Tesis. Depok: Fakultas Ilmu Keperawatan Universitas Indonesia. Tersedia di lib.ui.ac.id/file?file=digital/20280162T\%20 Aini\%20Yusra.pdf [Sitasi 19 Juli 2017]. 